\title{
MEDIA YOUTUBE SEBAGAI SARANA PEMEROLEHAN BAHASA B2 ANAK USIA 3-5 TAHUN (STUDI KASUS DUA ORANG ANAK)
}

\section{YOUTUBE MEDIA AS A MEANS OF THE LANGUAGE ACQUISITION OF B2 CHILDREN AGE 3-5 YEARS (CASE STUDY ON TWO CHILDREN)}

\author{
Farah Nur Fakhriyah \\ UIN Syarif Hidayatullah Jakarta \\ Pos-el: farahnur.fakhriyah17@mbs.uinjkt.ac.id
}

\begin{abstract}
This study aims to explain the problem of obtaining a second language in a case study of two children through watching that is watched on social media YouTube. YouTube social media is social media that can be used by various groups. Likewise, in children who are still at the stage of language acquisition. YouTube social media is a very effective media used in language acquisition in children, especially in the process of acquiring children's language B2. This study uses a qualitative method and a descriptive approach in which the researcher conducts an interview, then presents and presents it in the form of a descriptive description. Respondents in this study were two children, the first was a boy named Mubammad Alman Aqmar Permana aged 3 years 8 months and the second case study was a 5 years old girl named Fabira Putri Hendriansyah. This study aims to explain the acquisition of a second language, namely English which focuses on color nouns and basic numerals. Second language acquisition can only be absorbed by children in the form of words. Based on the results of this study, it can be seen that the YouTube media can influence the acquisition of B2 language of children. However, the YouTube media does not fully substantiate the role of bumans in acquisition or language learning.
\end{abstract}

Keywords: language acquisition, second language

\begin{abstract}
Abstrak
Penelitian ini bertujuan untuk menjelaskan masalah pemerolehan bahasa kedua pada studi kasus dua orang anak melalui tontonan yang disimak pada media sosial YouTube. Media sosial YouTube merupakan media sosial yang dapat digunakan oleh berbagai kalangan. Begitu pun pada anak-anak yang masih pada tahap pemerolehan bahasa. Media sosial YouTube menjadi media yang sangat efektif digunakan pada pemerolehan bahasa pada anak, terlebih lagi pada proses pemerolehan bahasa anak B2. Penelitian ini menggunakan metode kualitatif dan pendekatan deskriptif, peneliti melakukan wawancara, kemudian memaparkan dan menyajikan dalam bentuk uraian deskriptif. Responden pada penelitian ini ialah dua orang anak, yang pertama ialah seorang anak laki-laki yang bernama Muhammad Alman Aqmar Permana yang berusia 3 tahun 8 bulan dan studi kasus kedua ialah seorang anak perempuan berusia 5 tahun yang bernama Fahira Putri Hendriansyah. Penelitian ini bertujuan menjelaskan pemerolehan bahasa kedua, yaitu bahasa Inggris yang terfokus pada nomina warna dan numeralia pokok. Pemerolehan bahasa kedua dapat diserap anak dalam bentuk kata. Berdasarkan hasil penelitian ini, dapat dapat diketahui bahwa media YouTube dapat berpengaruh pada pemerolehan bahasa B2 anak. Akan tetapi, media YouTube tidak sepenuhnya menyubstitusikan peran manusia dalam pemerolehan ataupun pembelajaran bahasa.
\end{abstract}

Kata kunci: pemerolehan bahasa, bahasa kedua 


\section{PENDAHULUAN}

Pengaruh media sosial marak terjadi dewasa ini, di antaranya adalah YouTube yang merupakan media sosial berbasis video yang sangat sering diakses. Beberapa konten dapat ditemukan di dalam media sosial YouTube, seperti pembelajaran, berita, video musik, prosedur pembuatan sesuatu, acara, dan lain-lain. YouTube adalah situs yang dapat digunakan seseorang untuk mencari informasi berupa video, yang di dalamnya terdapat audio dan visual. Berselancar di YouTube tidak hanya untuk mencari video yang diinginkan, situs YouTube dapat pula digunakan untuk mengunggah dan membagikan video yang dimiliki ke jagat raya dunia (Muhaemin, 2017; Putra, 2018: 160).

Pemerolehan bahasa (language acquisition) dapat terjadi pada pemerolehan bahasa pertama (B1) atau yang lebih dikenal dengan bahasa ibu, maupun pemerolehan bahasa kedua (B2), dalam hal ini dapat berupa bahasa asing. Pemerolehan bahasa yang diteliti dalam penelitian ini adalah pemerolehan bahasa B2 pada anak yang diperoleh melalui media sosial berbasis video, yaitu YouTube yang saat ini digunakan oleh berbagai kalangan. Anak-anak menyaksikan video di YouTube sangat memerlukan pengawasan dari orang tuanya karena banyak hal yang mungkin terjadi atau tontonantontonan yang tidak sesuai dengan usia anak tersebut dalam sosial media. Kurniati (2020: 30) menyatakan bahwa pengaruh media sosial berimbas tidak hanya bagi orang dewasa, juga bagi anakanak. Apabila penggunaan berlebihan, pengaruh negatif mungkin saja merambah pada diri anakanak. Namun, positifnya, kerapkali dapat ditemukan pada anak-anak yang cenderung cerdas karena sering disuguhkan tontonan dan meniru apa yang ada di YouTube.

Pemerolehan bahasa seorang anak bersifat natural atau alami, juga dilakukan secara informal. Pemerolehan bahasa B2 pada penelitian ini adalah bahasa asing, yaitu bahasa Inggris, dengan menggunakan media sosial berbasis video yang saat ini sering disaksikan oleh seluruh kalangan, yaitu YouTube.

Anak-anak dapat dijadikan sebagai subjek penelitian karena keluguan dan natural dalam menyikapi sesuatu. Penelitian terhadap anak-anak lebih mengasyikkan dan menantang karena harus diteliti secara perlahan untuk mendapatkan informasi. Objek dalam penelitian ini merupakan anak generasi milenial yang sejak balita sudah disuguhkan gadget, begitulah kehidupan dan kekhasan anak-anak di era modern ini.

Pembelajaran bahasa B2 jika ditinjau dari sisi urutan pemerolehan bahasanya, yaitu setelah mempelajari atau memperoleh bahasa B1. Kebanyakan anak di Indonesia, bahasa Indonesia merupakan bahasa B2 karena banyak anak Indonesia yang memiliki B1, yaitu bahasa ibu, berupa bahasa daerah, tetapi bahasa B2 lazimnya digunakan sebagai pembelajaran bahasa asing. Pada penelitian ini, bahasa B2 yang digunakan adalah bahasa asing, yaitu bahasa Inggris.

Penelitian terkait dengan pemerolehan bahasa pada anak usia 3-5 tahun pernah dilakukan sebelumnya oleh Nurjamiaty dengan penelitiannya yang berjudul "Pemerolehan Bahasa Anak Usia Tiga Tahun Berdasarkan Tontonan Kesukaannya Ditinjau dari Kontruksi Semantik”, Jurnal Edukasi Kultura Vol. 2 No. 2 September 2015. Penelitian tersebut menghasilkan proses pemerolehan bahasa yang terjadi pada anak usia tiga tahun dengan tontonan kesukaannya, kartun Boboboy, kemudian anak yang diteliti meniru tuturan yang terdapat dalam kartun tersebut. Lalu, penelitian selanjutnya pernah dilakukan oleh Yulia Eka Salnita, Atmazaki, dan Abdurrahman dengan penelitiannya yang berjudul "Pemerolehan Bahasa pada Anak Usia 3 Tahun" yang dimuat ke dalam jurnal Obsesi: Jurnal pendidikan Anak Usia Dini Vol. 3, 2019. Penelitian tersebut menghasilkan tataran fonologi, sintaksis, dan tataran semantik pada anak usia 3 tahun. 
Perbedaan antara penelitian yang telah dilakukan dengan penelitian ini adalah jumlah objek penelitiannya. Penelitian ini menggunakan dua objek untuk memperkaya data. Perbedaan kedua, yaitu media yang digunakan. Penelitian ini lebih mengedepankan teknologi internet mengingat saat ini, manusia tidak lepas dari penggunaan IT (Information Technology). Penelitian menggunakan media YouTube, tidak lagi menggunakan media televisi, karena media YouTube dinilai telah banyak digunakan oleh kalangan anak-anak, terlebih ada di dalamnya fitur YouTube Kids yang dapat dimanfaatkan sebagai pembelajaran anak.

\section{LANDASAN TEORI}

Psikolinguistik merupakan gabungan dari dua ilmu, yaitu psikologi dan linguistik. Ilmu psikolinguistik mulai mencuat pada permulaan abad ke20. Psikolog dari Jerman Wilhelm Wundt mengungkapkan bahwa bahasa dapat dijelaskan dengan menggunakan dasar psikologis (Dardjowidjojo, 2014: 2). Psikolinguistik sebagai sebuah disiplin ilmu yang mandiri. Psikolinguistik merupakan ilmu yang berupa hibridasi. Termasuk tokoh-tokoh yang terdapat dalam ilmu psikologi dan ilmu bahasa ikut berkontribusi pula dalam sejarah atau perkembangan psikolinguistik. Kajian yang terdapat dalam psikolinguistik juga di dalamnya terdapat kajian ilmu psikologi dan ilmu lingustik yang dipakai untuk menjelaskan dan melengkapi (Sudarwati, dkk, 2017: 7).

Pemerolehan dapat digunakan sebagai suatu perkembangan kemampuan berbahasa, yaitu dengan cara natural atau tanpa diajarkan, sedangkan, pembelajaran bahasa ialah proses untuk mendapatkan pengetahuan yang baru mengenai bahasa, seperti pembelajaran mengenai unsurunsur yang terdapat dalam sintaksis suatu bahasa dan pembelajaran tersebut lazimnya dilakukan di dalam kelas, dalam bentuk formal dan dengan bantuan pengajar (Yule, 2014: 187).
Pemerolehan bahasa (language acquisition) merupakan suatu hal yang penting untuk diteliti. Pemerolehan (acquisition) suatu proses seseorang mendapatkan kemampuan untuk menangkap, menghasilkan, dan menggunakan kata-kata yang dapat dipahami untuk berkomunikasi. Hal-hal tersebut juga berkaitan dengan beberapa kemampuan berbahasa yang lain, seperti fonetik, sintaksis, dan memerlukan kosakata yang luas pula (Sundari, 2018: 54).

Pemerolehan bahasa merupakan suatu hal yang lazim dibincangkan dalam aspek kognitif kebahasaan. Pemerolehan bahasa memiliki subjek penelitian dan subjek yang digunakan dalam pemerolehan bahasa biasanya adalah anak-anak. Pada kenyataannya, anggapan itu tidak benar. Pemerolehan bahasa juga dapat menggunakan subjek penelitian lain, yaitu orang dewasa. Hal yang membedakan antara pemerolehan bahasa anak-anak dan orang dewasa dengan menciptakan waktu dalam pemerolehan bahasa, hal tersebut menjadikan penciptaan pembeda, yaitu istilah pemerolehan dan pembelajaran (Kushartanti, 2005: 24). Sedangkan, Purba (2017: 1) mengungkapkan bahwa pemerolehan bahasa pertama ataupun kedua mendasari proses pemerolehan bahasa tersebut bagaimana dapat terjadi. Teori yang umum dan mendasar yang digunakan pada pemerolehan bahasa pertama ataupun kedua adalah teori behaviorisme, karena teori tersebut dianggap paling mendasar mengenai pemerolehan bahasa. Teori yang lain yang terdapat pada kajian ilmu psikolinguistik. Menurut pandangan teori pemerolehan bahasa behaviorisme dilandasi sesuatu yang beranggapan bahwa seorang anak yang baru saja dilahirkan tidak memiliki apa-apa atau tidak membawa struktur linguistik apapun, anak tersebut dianggap kosong dari segi kebahasaan. Sehingga, dalam pemerolehan bahasa lingkungan memiliki peran aktif dalam pembentukan abahasa anak, lingkungan memiliki peran yang 
sangat penting. Seperti yang terjadi pada penelitian ini, anak dengan mudahnya meresapi apa yang ia lihat dan dengar melalui media YouTube, anak lebih mudah menangkap dan mengingat apa yang telah ia lihat dan dengarkan, dalam penelitian ini adalah B2 yang terfokus pada pengetahuan mengenai nomina warna dan numeralia pokok.

Penelitian ini terarah kepada pandangan teori pemerolehan bahasa behaviorisme karena menurut penulis seorang anak yang baru saja lahir tidak memiliki pengetahuan mengenai bahasa sedikit pun. Seorang anak memperoleh bahasa pertama melalui orang tuanya yang lebih dikenal dengan istilah B1. Hal tersebut dipengaruhi oleh suatu innate capacities atau kapasitas yang telah dibawa oleh manusia sejak lahir yang terbentuk dari lingkungan (Hyams \& Orfitelli. 2015: 1). Lingkungan memengaruhi bahasa anak karena memori pada otak anak akan menangkap apa yang didengarkan di sekitar lingkungan. Pemerolehan bahasa kedua (B2) pada anak didapatkannya setelah mendapatkan bahasa pertama atau bahasa ibu (B1). Bahasa pada seseorang didapatkan melalui pemerolehan bahasa secara natural atau informal, atau dengan formal. Menurut teori pemerolehan bahasa behaviorisme, pemerolehan bahasa seseorang didapat berdasarkan pengalaman, pada anak-anak didapatkan secara natural mengikuti bahasa ibunya. Lalu, dengan pengalaman itu pula yang juga berdasarkan faktor-faktor, dalam penelitian ini pemerolehan bahasa B2 anak diperoleh dari faktor media sosial YouTube.

Pemerolehan melibatkan berbagai kemampuan berbahasa, seperti sintaksis, fonetik, dan kosakata yang luas pada bahasa pertama, kedua, ketiga, dan seterusnya disebut bahasa target (Target Language). Lazimnya, bahasa merujuk pada pemerolehan bahasa pertama, yaitu mengkaji bahasa ibu. Jika pemerolehan yang biasanya digunakan pada bahasa ibu digunakan pada bahasa B2, maka pemerolehan bahasa B2 dapat diartikan sebagai sebuah proses anak untuk dapat menghasilkan, menangkap, dan menggunakan kata secara spontan atau tak sadar untuk berkomunikasi (Troike, 2005: 2-3). Pemerolehan bahasa B2 anak diperoleh setelah anak menguasai bahasa ibunya. Pemerolehan bahasa dalam penelitian ini diperoleh dari media YouTube, kemudian anak dapat memahami dan mencerna kata yang ia dengarkan, kemudian dilantunkan dalam kehidupan seharihari, yang menjadi fokus pada penelitian ini adalah pengetahuan nomina warna dan numeralia pokok.

\section{METODE PENELITIAN}

Penelitian ini menggunakan jenis metode kualitatif dan menggunakan pendekatan deskriptif. Moleong (2010: 6) menyatakan bahwa penelitian metode kualitatif menghasilkan prosedur analisis dan tidak menggunakan prosedur analisis statistik ataupun dengan cara kuantifikasi lainnya. Sudaryanto dalam Muhammad (2016: 192) mengemukakan bahwa pendekatan deskriptif dilakukan berdasarkan dengan fakta-fakta yang ada ataupun fenomena yang secara empiris hidup pada penuturnya, sehingga yang dihasilkan dari pendekatan deskriptif atau yang dapat dicatat berupa pemerian bahasa yang dikatakan paparan apa adanya. Berdasarkan penelitian ini, data metode kualitatif berupa percakapan antara penutur dan kawan tutur. Sedangkan, pendekatan deskriptif yaitu analisis yang digunakan dicatat berdasarkan fakta yang ada dan apa adanya.

Peneliti dalam hal ini adalah penulis sangat berperan sebagai instrumen kunci karena perlu mempertimbangkan berbagai aspek di antaranya adalah daya simak dan daya ingat mengenai kejadian yang dilakukan saat melakukan penelitian. Penelitian ini didukung oleh rekaman dan kemudian ditranskrip menjadi sebuah data yang dicantumkan sebagaimana tertulis dalam penelitian ini. Perekaman yang dilakukan hanya menggunakan perekam audio, sehingga daya ingat penulis pada kejadian 
penelitian harus diingatkan. Perekaman audio dilakukan dengan empat buah rekaman yang setiap rekamannya berisi sebuah peristiwa tuturan. Alat perekam yang digunakan adalah aplikasi perekam suara yang terdapat pada Samsung Galaxy S8+.

Studi kasus pada penelitian ini adalah dua orang anak pada usia 3-5 tahun. Peneliti mencoba menganalisis dengan cara mengajak berbicara untuk memperoleh informasi mengenai pengetahuan B2 anak yang diperoleh dari media YouTube. Berdasarkan fenomena yang ada dari kedua anak tersebut. Keduanya memiliki pengetahuan yang berbeda, yakni anak yang diteliti adalah berjenis kelamin laki-laki dan perempuan dengan penelitian yang berbeda. Anak laki-laki diteliti adalah pengetahuannya mengenai nomina warna yang diketahui dalam bahasa Inggris. Sedangkan, pada anak perempuan yang diteliti adalah pengetahuannya mengenai numeralia pokok dalam bahasa Inggris. Keduanya mendapatkan pengetahuan tersebut dari media sosial berbasis video YouTube yang disuguhkan oleh orang tuanya seharihari, secara tidak sadar anak-anak tersebut memperoleh bahasa dan memakainya saat berbicara sehari-hari.

Analisis penuturan dilakukan terhadap kedua anak tersebut, yaitu pada saat keduanya bermain atau berbincang dengan keluarga. Kedua anak yang diteliti sangat responsif saat menjawab beberapa pertanyaan yang disampaikan untuk memenuhi penelitian ini. Strategi peneliti saat meneliti kedua anak tersebut adalah merekamnya secara diam-diam tanpa diketahui oleh anak yang diteliti. Selain metode yang disampaikan, terdapat pula beberapa sumber lain yang digunakan pada penelitian ini antara lain buku, sesuatu jurnal, dan artikel.

\section{PEMBAHASAN}

Anak adalah peniru ulung yang mengikuti orang tuanya. Oleh sebab itu, bahasa B1 anak akan sama dengan bahasa ibunya. Namun, pemerolehan bahasa B2 anak dapat diperoleh dari pihak lain selain orang tua ataupun lingkungan sekitar, dalam hal ini dengan menggunakan media sosial. Seorang anak yang sering menyaksikan atau mendengarkan sesuatu pasti akan terekam di memori otaknya. Terlebih dari itu, memori yang dimiliki anak masih belum banyak terisi sepenuhnya, sehingga hal itu memungkinkan anak untuk menyimpan memori yang lebih dalam. Memori terbagi menjadi dua, yaitu memori jangka panjang dan jangka pendek. Pemerolehan bahasa yang terus terlatih akan menjadi memori jangka panjang dan akan selalu teringat oleh seseorang, terutama seorang anak (James; Nuryani \& Putra, 2013: 50). Jika seorang anak terlatih atau biasa diberi edukasi mengenai pemerolehan bahasa B2, dalam hal ini adalah bahasa Inggris, baik dari media YouTube ataupun lainnya, maka hal itu dapat selalu teringat dan tersimpan dalam memori jangka panjang.

Studi bahasa B2 pada anak ini termasuk dalam studi psikolinguistik terapan. Psikolinguistik terapan ialah pengaplikasian teori psikolinguistik di kehidupan sehari-hari, baik pada orang dewasa maupun kanak-kanak (Levelt; Mar'at, 2015:1-2). Seperti yang telah dipaparkan, penelitian ini menggunakan teori pemerolehan bahasa behaviorisme, yang mana seorang anak menuturkan atau menjawab pertanyaan menggunakan bahasa B2 berdasarkan dari kebiasaan dan pengalamannya, dalam hal ini media YouTube menjadi sumber pembelajaran bagi anak karena telah menjadi kebiasaan anak menyaksikan video pembelajaran anak di media YouTube, anak memperoleh bahasa B2 tersebut secara natural.

Studi kasus pada penelitian ini adalah dua orang anak (laki-laki dan perempuan) yang berusia antara 2-5 tahun yang kesehariannya disuguhi video dari media sosial YouTube oleh orang tuanya dengan tujuan awalnya agar anak tersebut tidak bosan. Seringnya disuguhi media sosial YouTube 
tersebut menjadikan anak tersebut kecanduan dan sukar untuk berpaling dari smartphone. Namun, pengawasan orang tua tetap tidak luput dari konten yang disaksikan oleh anak. Orang tua memilah video yang layak ditonton. Dalam media sosial berbasis video, YouTube juga tersedia fitur untuk anak-anak agar YouTube itu digunakan oleh anak tidak berbahaya atau terdapat sesuatu di luar kendali orang tua karena dalam media YouTube juga terdapat banyak konten yang tidak seharusnya dilihat oleh anak di bawah umur. Jika ingin lebih aman, YouTube menyediakan fitur YouTube Kids untuk digunakan oleh anak-anak.

\section{Pemerolehan Kosakata Dasar B2}

Pemerolehan kosakata dasar, dalam hal ini adalah kosakata sederhana dalam pemerolehan bahasa B2 anak, antara lain terdiri atas nomina dan kata bilangan atau numeralia karena kedua kelas kata tersebut adalah kata yang mudah diserap oleh anak dalam pemerolehan bahasa B2. Kata benda dalam hal ini adalah berupa nomina warna, anak menyebutkan warna menggunakan bahasa Inggris karena pemerolehan bahasa yang ia tiru dari tontonan di YouTube. Kata bilangan atau numeralia dalam hal ini adalah berupa angkaangka pokok, yaitu dari 1 hingga 10, anak menyebutkan angka menggunakan bahasa Inggris secara urut maupun acak. Penelitian ini menggunakan empat peristiwa tuturan dari dua objek penelitian yang berbeda, masing-masing terdapat dalam dua peristiwa tuturan.

Objek penelitian yang pertama, yaitu Muhammad Alman Aqmar Permana, seorang anak berusia 3 tahun lebih 8 bulan dan berjenis kelamin laki-laki. Alman merupakan sepupu penulis, yaitu anak dari adik orang tua penulis yang bertempat tinggal di Kp. Setu, RT 005/01, Bintara Jaya, Bekasi Barat. Alman disuguhi tontonan melalui media sosial YouTube oleh orang tuanya, tetapi tidak lepas dari pengawasan orang tuanya. YouTube yang biasa disaksikan oleh Alman adalah serial kartun Upin \& Ipin, serial kartun Thomas and Friends, dan yang paling sering disaksikan adalah video pembelajaran menggunakan bahasa Inggris pada channel YouTube yang bernama "CocomelonNursery Rbymes".

\section{Peristiwa Tuturan 1}

Farah : "Dek Al, liat baju aku. Ini warna apa?"

Alman : "Warna red!"

Farah : Kalau.. gelas ini warna apa nih?"

Alman : "Blue!"

Farah : "Blue tuh warna apa sih?"

Alman : "Biru"

Farah : "Kalau ungu itu apa?"

Alman : "Purple!"

Farah : "Ih pintar. Kalau kerudung Ibu warna apa, Dek Al?"

Alman : "Grey!"

Peristiwa tuturan yang pertama, pada cuplikan peristiwa tersebut, penutur menanyakan warna kepada lawan tutur sebagai objek penelitian. Warna yang ditanyakan bersifat acak sesuai dengan warna benda yang ada di sekitar lokasi penelitian. Lawan tutur menjawab dengan benar seluruh pertanyaan yang dituturkan oleh penutur. Kawan tutur menjawabnya sesuai pengetahuan pemerolehan bahasa atau kata-kata tersebut dari konten YouTube yang disaksikannya. Lawan tutur memperoleh pengetahuan dari konten YouTube yang disaksikan, terdapat berbagai contoh warna, yang kemudian dengan kemampuan motorik dan memori yang dimiliki anak, ia dapat mengingat warna tersebut. Warna yang diingat oleh kawan tutur bukan hanya warna yang mudah diingat atau umum seperti warna primer, yaitu merah, kuning, dan biru. Warna lain yang termasuk warna yang tidak umum atau warna sekunder, seperti ungu yang merupakan campuran dari merah dan biru, ataupun abu-abu yang merupakan campuran dari warna hitam dan putih juga diingat, meskipun warna-warna tersebut jarang ditemukan atau 
ditanyakan. Hal ini membuktikan bahwa memori yang dimiliki seorang anak, yaitu memori yang panjang, karena dapat mengingat dalam waktu yang lama, terlebih jika sering diasah atau ditanyakan mengenai hal tersebut. Memori yang dimiliki anak masih belum terisi banyak, sehingga ia mampu menghafal dan menyimpan suatu kosakata dengan mudah.

\section{Peristiwa Tuturan 2}

Alman : "Ayah, susu"

Ayah : "Iya, sabar sebentar"

Farah : "Dek Al, susu terus nih"

Alman : "Susu enak susu"

Farah : "Susunya warna apa emang?"

Alman : "White!"

Farah : "Ah, putih kali.."

Alman : "White?"

Farah : "White emang warna apa?"

Alman : "Warna... putih,"

Farah : "Berarti susunya putih dong?"

Alman : "White!"

Peristiwa tuturan yang kedua, pada cuplikan peristiwa tersebut, penutur memotong pembicaraan lawan tutur dengan lawan tutur yang lain, penutur menyanggah sesuatu yang diinginkan oleh lawan tutur dan menanyakan terkait warna. Warna yang ditanyakan oleh penutur belum terlihat visualnya, tetapi lawan tutur menjawab dengan benar menggunakan bahasa Inggris. Tuturan warna dalam bahasa Inggris lebih sering digunakan oleh lawan tutur daripada tuturan warna dalam bahasa Indonesia. Hal ini menyebabkan mitra tutur tidak menerima jika warna tersebut dikatakan dalam bahasa Indonesia. Sejatinya, mitra tutur mengetahui bahwa arti dari kata white adalah putih, tetapi mitra tutur tidak menerima jika susu dikatakan oleh penutur berwarna putih, mitra tutur tetap berkata bahwa itu adalah warna white. Hal tersebut merupakan dampak yang terjadi pada anak usia 3-5 tahun yang memperoleh bahasa B2 dari YouTube, karena memori ingatan yang dimiliki anak tersebut adalah memori jangka panjang. Lawan tutur tetap teguh menuturkan bahwa susu itu berwarna white, pengetahuan mengenai nomina warna lebih dahulu diterimanya melalui media YouTube dibandingkan dengan orang tua yang mengajarkan kawan tutur mengenai pengetahuan nomina warna. Hal tersebut membuktikan bahwa pemerolehan bahasa yang berasal dari media yang berupa audio dan visual dapat diterima anak secara natural dan dapat diingatnya.

Objek penelitian yang kedua, yaitu Fahira Putri Hendriansyah atau akrabnya dipanggil dengan sebutan Aira, seorang anak berusia 5 tahun dan berjenis kelamin perempuan. Aira juga merupakan sepupu penulis, yaitu anak dari adik orang tua penulis yang bertempat tinggal di Perumahan Alam Pesona Wanajaya, Blok P25 No. 20, Wanajaya, Cibitung, Kabupaten Bekasi. Aira saat ini mulai bersekolah di Taman Kanak-kanak. Aira disuguhi tontonan melalui media sosial YouTube oleh orang tuanya seusai pulang sekolah, tetapi tidak lepas dari pengawasan orang tuanya pula. YouTube yang biasa disaksikan oleh Aira adalah kartun Unicorn, kartun Frozen, dan video pembelajaran menggunakan bahasa Inggris pada beberapa channel YouTube. Namun, Aira juga menyukai tontonan yang berupa kebudayaan Indonesia, ia sering meminta untuk menyaksikan ondel-ondel di YouTube.

\section{Peristiwa Tuturan 3}

Fahira : "Kakak, temenin dedek jajan."

Farah : "Itung dulu satu sampai sepuluh, baru jajan."

Fahira : "Gak mau."

Farah : "Ya udah Aira jajan sendiri."

Fahira : "Itung deh. Satu, dua, tiga, empat, lima, enam, tujuh, delapan, sembilan, sepuluh."

Farah : "Nah, gitu. Coba pake bahasa Inggris dulu." 
Fahira : "Gak mau, ah, kakak mah. Jajan..."

Farah : "Iya, jajan, Aku pake kerudung dulu.

Aira itung satu sampai sepuluh pake bahasa Inggris dulu tapi."

Fahira : "One, two, three, four... ah, udah ah. Ayo, jajan dulu, Kak."

Farah : "Lanjutin sampai sepuluh baru kita keluar."

Fahira : "Tadi sampe mana? Eh, iya, sampe three. four, five, six, seven, eight, nine, ten. Udah. Ayo, Kakak, jajan."

Farah : "Nah, gitu dong. Ayo, kita jajan"

Peristiwa tuturan yang ketiga, pada cuplikan peristiwa tersebut, penutur memerintahkan kepada lawan tutur untuk berhitung dari angka satu hingga sepuluh dan lawan tutur menuruti perintah dari penutur dan menyebutkan angkaangka tersebut menggunakan bahasa Indonesia. Kemudian, penutur memerintahkan kembali kepada lawan tutur untuk menyebutkan angkaangka yang telah disebutkan dalam bahasa Inggris. Lawan tutur menyebutkannya, tetapi di tengah tuturan lawan tutur merasa jenuh dan kemudian tetap melanjutkan. Usia objek penelitian pada peristiwa tuturan ketiga lebih besar daripada objek penelitian pertama dan kedua, dilihat dari tingkat pendidikan pula subjek penelitian ketiga sudah bersekolah di Taman Kanak-kanak, sehingga hal tersebut menyebabkan objek penelitian selaku lawan tutur sudah jenuh jika ditanyakan terkait hal tersebut karena mungkin di sekolah telah banyak diajarkan oleh guru. Berbeda dengan objek penelitian pada peristiwa tuturan pertama dan kedua yang usianya lebih muda maka ia lebih responsif terhadap apa yang ditanyakan oleh penutur.

\section{Peristiwa Tuturan 4}

Farah : "Aira, ayok, belajar angka pake bahasa Inggris ya, ini angka berapa, Dek?" (menunjukkan angka 4 menggunakan jari)
Fahira : "Hmm.. Four!"

Farah : "Kalau ini?" (menunjukkan angka 9 menggunakan jari)

Fahira : "Nine!"

Farah : "Kalau sebelas, dua belas, itu apa bahasa Inggrisnya?"

Fahira : "Eleven, ah, gak tau aku gak mau itu susah."

Farah : Ya, udah ini nih berapa, nih?" (menunjukkan angka 7 menggunakan jari)

Fahira : Seven!"

Peristiwa tuturan yang keempat, pada cuplikan peristiwa tersebut, penutur mengajak lawan tutur mengulas kembali apa yang diketahui oleh kawan tutur dengan cara mengajak belajar bahasa Inggris dengan berhitung menggunakan bahasa Inggris. Penutur memeragakan angka menggunakan jari, kemudian lawan tutur menyebutkan angka tersebut dengan bahasa Inggris yang telah diperolehnya dari video di YouTube. Lawan tutur hanya lancar berhitung menggunakan bahasa Inggris dari satu hingga sepuluh. Sehingga, saat penutur menanyakan angka sebelas, dan seterusnya, kawan tutur berkata bahwa itu adalah hal yang sulit. Dalam pemerolehan bahasa, satu kata lebih mudah dihafalkan oleh anak usia balita dibandingkan satu frasa. Balita lebih mudah menghafal terlebih jika sering dilatih atau ditanyakan oleh orang-orang di lingkungan sekitarnya.

Berdasarkan empat tuturan dari kedua studi kasus, dapat dilihat bahwa anak yang pertama, yaitu Muhammad Alman Aqmar Permana, memperoleh bahasa B2 mengenai nomina warna. Kedwibahasaan yang dimiliki Alman yakni lebih mengutamakan pengetahuan nomina warna dengan bahasa B2, hal ini dipengaruhi karena orang tua yang belum intensif mengajarkan pengetahuan nomina warna menggunakan bahasa ibu atau B1. Media YouTube sangat memengaruhi pengatahuan Alman karena diperolehnya dengan natural dan tanpa ada pembelajaran formal yang 
melatarbelakangi atau tanpa ada pengajar. Usia juga memengaruhi karena usia Alman masih cukup dini, Kusno (2017: 40) mengemukakan bahwa anak pada usia dini masih berada dalam masa keemasan, yaitu sepanjang rentang usia perkembangan manusia.

Pada studi kasus anak kedua, yaitu Fahira Putri Hendriansyah, pemerolehan bahasa B2 yang difokuskan adalah mengenai numeralia pokok, yaitu angka 1 sampai 10. Kedwibahasaan yang dimiliki Fahira lebih mendominasi bahasa ibu atau B1, hal ini dipengaruhi karena Fahira telah mendapatkan pendidikan formal, yakni di Taman Kanak-kanak yang pengajarnya lebih sering mengajarkan numeralia pokok menggunakan bahasa Indonesia, atau faktor lain, seperti kejenuhan karena usia yang hampir tidak dikatakan balita. Berdasarkan pemaparan dan faktor-faktor tersebut berarti media YouTube tidak sepenuhnya menyubstitusikan peran manusia dalam pemerolehan ataupun pembelajaran bahasa.

\section{PENUTUP}

Media sosial berbasis video yang marak digunakan saat ini, yaitu YouTube sangat memengaruhi pemerolehan bahasa B2 yang diteliti pada penelitian ini. Pemerolehan bahasa B2 yang diteliti adalah bahasa Inggris. Dalam aplikasi YouTube banyak terdapat video pembelajaran untuk anakanak yang menggunakan bahasa Inggris, sehingga dengan mudah orang tua menyuguhkan anaknya untuk belajar. YouTube memiliki peran penting dalam pemerolehan bahasa anak melalui channel yang ada di dalamnya, terutama pada fitur YouTube Kids, yang memang didesain khusus untuk anak. Pembelajaran bahasa anak dapat dipelajari melalui media YouTube, visual dan audio dalam YouTube menarik dan memudahkan anak memperoleh bahasa dan mengingat bahasa dengan baik. Dalam penelitian ini, YouTube sangat berperan untuk pengetahuan mengenai nomina warna dan numeralia pokok pada kedua anak yang diteliti.

Anak memiliki memori otak yang cukup besar sehingga seorang anak dapat menyimpan suatu kata yang ia peroleh dalam jangka waktu yang panjang jika terus dilatih. Peran pengajar juga diperlukan dalam pemerolehan ataupun pembelajaran bahasa anak, karena media tidak sepenuhnya menyubstitusikan peran manusia dalam pemerolehan ataupun pembelajaran bahasa. Tidak hanya anak yang dapat memperoleh bahasa B2 melalui media audio visual, dewasa pun dapat dijadikan objek penelitian kedepannya dalam hal ini.

\section{DAFTAR PUSTAKA}

Dardjowidjojo, Soenjono. 2014. Psikolinguistik: Pengantar Pemahaman Bahasa Manusia. Jakarta: Yayasan Pustaka Obor Manusia.

Hyams, Nina \& Robyn Orfitelli. 2015. "The Acquisition of Syntax." Handbook of Psycholinguistics. Blackwell Publishers. Retreived from http:/ / linguistics.ucla.edu/people/ byams/ 28\%20HyamsOrfitelli.final.pdf

Kurniati, Mulia dan Nuryani. 2020. "Pengaruh Sosial Media YouTube Terhadap Pemerolehan Bahasa Anak Usia 3-4 Tahun”, (Studi pada Anak Speech Delay). Dalam Jurnal FON: Jurnal Pendidikan Bahasa dan Sastra Indonesia. Vol. 16. No. 1.

Kushartanti, dkk. 2005. Pesona Bahasa: Langkah Awal Memahami Linguistik. Jakarta: Gramedia Pustaka Utama.

Kusno, Ali. 2017. "Perkembangan Fungsi Pragmatik pada Anak Usia 2,5 Tahun (Studi Kasus pada Azza Aqila Jihan Syuasabitha)". Dalam Jurnal Kadera. Vol. 9. No. 1. April.

Mar'at, Samsunuwiyati. 2015. Psikolinguistik: Suatu Pengantar. Bandung: PT Refika Aditama. 
Muhammad. 2016. Metode Penelitian Bahasa. Jogjakarta: Ar-Ruzz Media.

Moleong, Lexy J. 2010. Metode Penelitian Kualitatif. Bandung: PT Remaja Rosdakarya.

Nuryani dan Dona Aji Karunia Putra. 2013.

Psikolinguistik. Tangerang Selatan: Mazhab Ciputat.

Purba, Andiopenta. 2013. "Peranan Lingkungan Bahasa dalam Pemerolehan Bahasa Kedua". Dalam Jurnal Pena. Vol. 3. No. 1. Juli.

Putra, Asaas dan Diah Ayu Patmaningrum. 2018 "Pengaruh YouTube di Smartphone terhadap Perkembangan Komunikasi Interpersonal
Anak". Dalam Jurnal Penelitian Komunikasi. Vol. 21. No. 2. Desember.

Sudarwati, Emy, dkk. 2017. Pengantar Psikolinguistik. Malang: Universitas Brawijaya Press.

Sundari, Weli. 2018. "Pemerolehan Bahasa". Dalam Jurnal Warna. Vol. 2. No. 1. Juni.

Troike, Muriel Saville. 2005. Introducing Second Language Acquisition. New York: Cambridge University Press.

Yule, George. 2014. The Study of Language (Fifth Edition). New York: Cambridge University Press. 